\section{Effects of dark preference on attention to the positive cue in posterior neodecorticated albino rats}

\author{
LOIS O. STRATTON* \\ Louisiana State University in New Orleans, New Orleans, La. 70122
}

Transfer of attention to the relevant stimulus dimensions of a successive brightness discrimination was assessed by the "acquired distinctiveness of cues" method in posterior neodecorticated rats. Attention to the relevant cue was retarded when $S$ s responded trophically toward the dark in a simultaneous brightness problem. Dark preference was negatively correlated with effective performance of a subsequent successive problem.

Two-stage models of discrimination learning predict that rats will solve a problem more rapidly when they have first learned to attend to the relevant stimulus dimension (Mackintosh, 1965). Stratton \& Edwards (1971) found that occipitalectomized rats have a persistent dark preference which facilitates performance of a simultaneous (SI) problem when dark is the positive cue and retards performance when light is positive. Hypothetically, rats trained to respond toward their preferred cue would learn little about the stimulus dimensions of the problem, whereas rats responding against their preference would be forced to notice both cue dimensions of the task. Lawrence (1949) demonstrated that rats trained to respond to brightness cues on a SI discrimination were facilitated in learning a successive (SU) discrimination which followed. The present study used Lawrence's paradigm to evaluate transfer of attention from a SI to a SU problem when a preferred (dark) vs nonpreferred cue (light) was positive on a SI problem.

SUBJECTS AND APPARATUS

The Ss were 16 adult male Sprague-Dawley albino rats. Before training, all $\mathrm{Ss}$ received bilateral posterior neodecortication by the suction method under Nembutal sedation. Krieg's (1946) Areas 17, 18, $18 \mathrm{a}$, and parts of the surrounding tissue were removed, and extent of lesion was determined by autopsy at the end of the experiment (Fig. 1). After a 4-week recovery period, Ss were assigned randomly to either a dark (D) or light (L) positive group for the SI problem.

The Ss were trained in a Plexiglas-enclosed T-maze with shock avoidance motivation. $A$ detailed

*I am indebted to Dr. S. Thomas Elder and LSUNO for finarcial support of this research. Thanks to Cynthia Jones, Mary Woodin, and Bruce Bird for their assistance in various aspects of the research. description of the maze is found in Thompson et al (1961). Two 20-W cool white fluorescent bulbs installed 5 in. from the back of each arm illuminated the length of each alley. Milk-glass inserts separated maze and lights. A Grossen tri-lux meter placed at the choice point registered $9 \mathrm{fc}$ when directed at a lighted alley and 0 fc when directed at a dark alley.

$$
\text { PROCEDURE }
$$

The Ss were preadapted to the maze and pretrained to knock down goalbox (GB) doors under room light conditions. During SI acquisition, six trials a day were run to a criterion of $11 / 12$ correct responses in 2 days. The $\mathrm{L}$ or $\mathrm{D}$ positive cue was alternated according to a Gellerman series. Training on the SU problem began
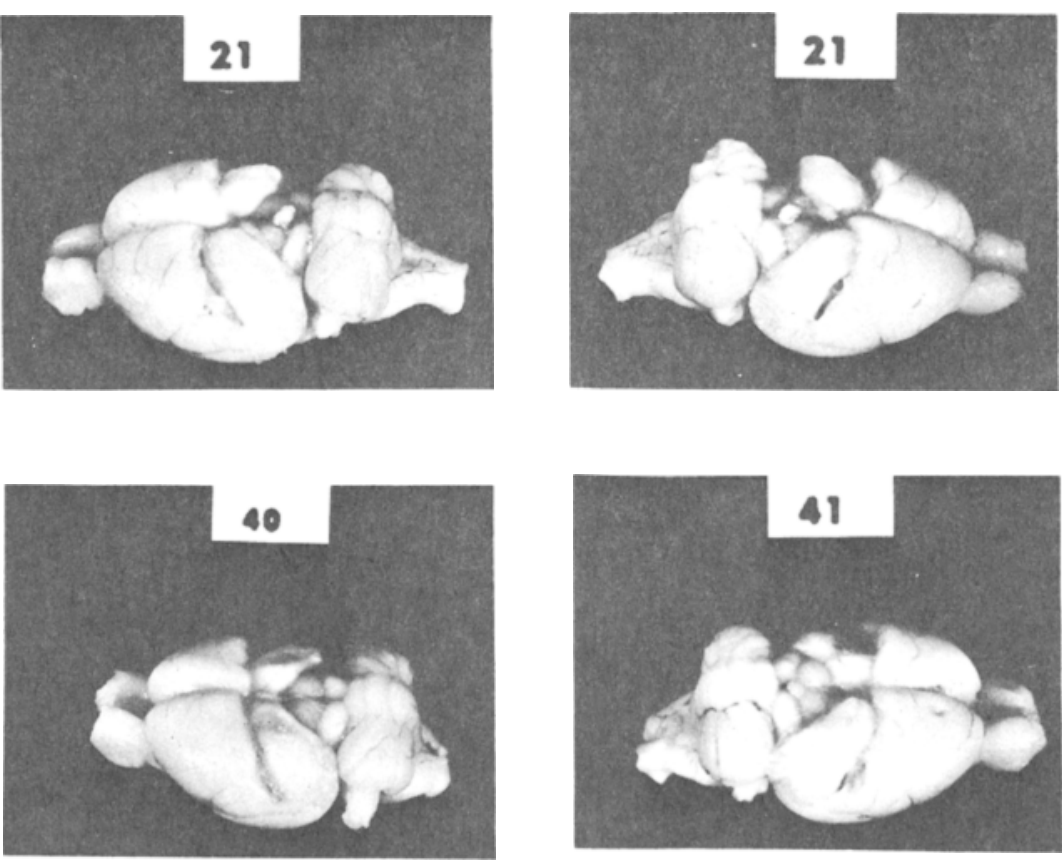

immediately after 5 days of overtraining on SI. For the SU problem, the right $G B$ was correct when both sets of lights were on, and the left GB was correct with both lights off. An error was recorded when a S's foot contacted the negative GB grid.

RESULTS AND DISCUSSION

Mean errors to criterion were 23.0 for $L$ and 3.6 for $D$ rats $(p<.001)$. These results agree with those of Stratton \& Edwards (1971), in which $L$ positive albinos made about six times as many errors as did Ds in learning a SI problem when high differential levels of illumination were used. The SU problem, generally more difficult for rats, took 19.0 errors for $\mathrm{Ls}$ and 25.7 for Ds $(p<.01)$. A correlation coefficient calculated on errors for the two problems indicated $a+.66$ correlation for $L(p<.01)$ and $-.53(\mathrm{p}<.08)$ for $\mathrm{D}$ rats.

Ablated albino rats prefer the dark, and posteriorly ablated rats have difficulty in overcoming their preference in order to learn a SI problem (Krechevsky, 1936). Apparently $\mathrm{D}$ Ss having the strongest dark preference learn the least about the sensory cues of the task and take longer to learn a second problem based on the same cues. The fact that $L$ rats had more SI learning trials does not explain their superior performance on SU, because Ss which learned SI most rapidly made the fewest errors on SU. Also, D positive rats were superior to 
Ls on overlearning trials $(\overline{\mathrm{X}} \mathrm{L}=4.6$; $\bar{X} \mathrm{D}=2.8$ ), so performance was not improved as a function of number of SI trials per se. The important factor contributing to learning $\mathrm{SU}$ was the ability to overcome preference responding in order to attend to the relevant stimulus source.

Following cortical ablation, brightness (Iuminous flux) discrimination is performed subcortically in the rat, probably in the pretecto-diencephalon (Thorne, 1970; Thompson \& Rich, 1961; Horel, 1968 ). Subcortical processing of visual information may account for the persistent negative phototrophic responding of ablated Ss. Trophic responding interferes with attention to the cues which guide choice behavior.

\section{REFERENCES}

HOREL, J. A. Effects of subcortical lesions on brightness discrimination acquired by rats without visual cortex. Journal of Comparative \& Physiological Psychology, $1968,65,103-109$.

KRECHEVSKY, 1. Brain mechanisms and brightness discrimination learning. Journal of Comparative Psychology, $1936,21,404-445$.

KRIEG, W. J.S. Connections of the cerebral cortex: I. The albino rat: $A$. Topography of the cortical areas. Journal of Comparative Neurology, 1946, 84, 221-275.

LAWRENCE, D. H. Acquired distinctiveness of cues: I. Transfer between discriminations on the basis of familiarity with the stimulus. Journal of Experimental Psychology, 1949, 39, 770-784.

MACKINTOSH, N. J. Selective attention in animal discrimination learning. Psychological Bulletin, 1965, 64. 124-140.

STRATTON, L. O., \& EDWARDS, S. Preference and stimulus factor in brightness discrimination learning of posterior neodecorticated albino rats Psychonomic Science, 1971, 24, 9-10.

THOMPSON, R., \& RICH, I. A. A diserete diencephalic pretectal area critical for the retention of visual habits in the rat. Experimental Neurology, 1961, 4. 436-443.

THOMPSON, R., DUKE, R. B., MALIN, C. F.\& HAWKINS. W. F. The interpeduncular nucieus and retention in albino rats. Journal of Comparative \& Physiological Psychology, 1961, 54, 329-333.

THORNE, M. Visual discrimination performance in rats following nucleus posterior thalamic and di-mesencephalic juncture damage. Journal of Comparative \& Physiological Psychology, 1970, 71, $136-146$.

\section{CURRENT LITERATURE ON BRAIN LESIONS AND BEHAVIOR}

BLASS, E. M. (Johns Hopkins University, Baltimore, Md. 21218). Effects of frontal-pole-area ablation on temperature regulation in the rat. Journal of Comparative and Physiological Psychology, 1971, 74, 233-239.

BURESOVÁ, O., BUREŚ, J. (Institute of Physiology, Czechoslovak Academy of Sciences, Budèjovická 1083, Praha 4-Krè, Czechoslovakia), \& RUSTOVÁ, M. Conditions for interhemispheric transfer of initially lateralized visual engrams in hooded rats. Journal of Comparative and Physiological Psychology, 1971, 75, 200-205.

DUNCAN, P. M. (Department of Physiology and Biophysics, University of Washington, Seattle, Wash. 98105). Effect of temporary septal dysfunction on conditioning and performance of fear responses in rats. Journal of Comparative and Physiological Psychology, 1971, 74, 340-348.

EICHELMAN, B. S., JR. (National Institute of Mental Health, Bethesda, Md. 20014). Effect of subcortical lesions on shock-induced aggression in the rat. Journal of Comparative and Physiological Psychology, 1971, 74, 331-339.

ENTINGH, D. (Neurobiology Curriculum, Department of Biochemistry, School of Medicine, University of North Carolina, Chapel Hill, N.C. 27514). Perseverative responding and hyperphagia following entorhinal lesions in cats. Journal of Comparative and Physiological Psychology, 1971, 75, 50-58.

FERGUSON, N. B. L., \& KEESEY, R. E. (University of Wisconsin, Madison, Wis. 53706). Comparison of ventromedial hypothalamic lesion effects upon feeding and lateral hypothalamic self-stimulation in the female rat. Journal of Comparative and Physiological Psychology, 1971, 74, 263-271.

FRIED, P. A. (Carleton University, Ottawa, Ontario, Canada). Limbic system lesions in rats: Differential effects in an approach-avoidance task. Journal of Comparative and Physiological Psychology, 1971, 74, 349-353.

GROSSMAN, S. P. (University of Chicago, Chicago, Ill. 60637). Changes in food and water intake associated with an interruption of the anterior or posterior fiber connections of the hypothalamus. Journal of Comparative and Physiological Psychology, 1971, 75, 23-31.

JONASON, K. R. (Department of Anatomy, State University of New York Upstate Medical Center, Syracuse, N.Y. 13210), \& ENLOE, L. J. Alterations in social behavior following septal and amygdaloid lesions in the rat. Journal of Comparative and Physiological Psychology, 1971, 75, 286-301.

KELSEY, J. E., \& GROSSMAN, S. P. (University of Chicago, Chicago, Ill. 60637 ). Non perseverative disruption of behavioral inhibition following septal lesions in rats. Journal of Comparative and Physiological Psychology, 1971, 75, 302-311.

MANNING, F. J. (Department of Experimental Psychology, Walter Reed Army Institute of Research, Walter Reed Army Medical Center, Washington, D.C. 20012). Punishment for errors and $v$ isual-discrimination learning by monkeys with inferotemporal cortex lesions. Journal of Comparative and Physiological
Psychology, 1971, 75, 146-152.

MOSS, R. L. (Department of Anatomy, University of Bristol Medical School, Bristol, BS8 1TD, England). Modification of copulatory behavior in the female rat following olfactory bulb removal. Journal of Comparative and Physiological Psychology, 1971, 74, 374-382.

ROUTTENBERG, A. (Northwestern University, Evanston, III. 60201). Forebrain pathways of reward in Rattus norvegicus. Journal of Comparative and Physiological Psychology, 1971, 75, 269-276.

THOMPSON, R. (Louisiana State University, Baton Rouge, La. 70803), \& MYERS, R. E. Brainstem mechanisms underlying visually guided responses in the rhesus monkey. Journal of Comparative and Physiological Psychology, 1971, 74, 479-512.

THOMAS, G. J. (Center for Brain Research, University of Rochester, Rochester, N.Y. 14627). Maze retention by rats with hippocampal lesions and with fornicotomies. Journal of Comparative and Physiological Psychology, 1971, 75, 41-49.

TRAFTON, C. L. (University of Arizona, Tucson, Ariz. 85721), \& MARQUES, P. R. Effects of septal area and cingulate cortex lesions on opiate addiction behavior in rats. Journal of Comparative and Physiological Psychology, 1971, 75, 277-285.

WAMPLER, R. S. (Kansas State University, Manhattan, Kans. 66502). Regulatory deficits in rats following unilateral lesions of the lateral hypothalamus. Journal of Comparative and Physiological Psychology, 1971, 75, 190-199. 